\title{
The Effect of Good Governance and Internal Control Systems on the Performance of Local Governments with Leadership Styles as Moderating Variables (Empirical Study on SKPD South Buton Regency)
}

\author{
Satia Siti Sakinah Makatita ${ }^{1}$, Kartini $^{2}$, Sri Sundari ${ }^{3}$ \\ ${ }^{1,2,3}$ Faculty of Economic and Business, Hasanuddin University, Makassar, Indonesia.
}

Corresponding Author: Satia Siti Sakinah Makatita

DOI: https://doi.org/10.52403/ijrr.20220164

\begin{abstract}
This study aims to examine and analyze the effect of good governance and internal control systems on local government performance with leadership style as a moderating variable. This research was conducted in Kab. South Buton by taking respondents from SKPD Kab. South Buton. Data was collected through questionnaires and literature study. Data analysis used descriptive quantitative approach with method survey with technique purposive sample. The results of this study indicate that (1) good governance has a positive and significant effect on the performance of local governments, (2) the internal control system has a positive and significant effect on the performance of local governments, (3) leadership style cannot moderate good governance on local government performance, (4) leadership style can moderate the internal control system on government performance. The contribution in this research is expected to provide information to interested parties, especially the next researcher and it is hoped that the results of this research can contribute ideas for relevant agencies in making policies or efforts to improve retention and performance.
\end{abstract}

Keywords: Good Governance, Internal Control System, Leadership Style, Local Government Performance

\section{INTRODUCTION}

In the current era of globalization, the Indonesian nation is part of the world community that has an obligation to continuously participate in realizing good governance to support competition in the era of globalization (Marchelino, 2013). Responding to this new paradigm, the government grants autonomy to the regions as wide as possible, which aims to enable regions to manage and regulate their own households so that they are efficient and successful in administering government and development as well as in the context of providing services to the community.

Since the enactment of Law no. 22 of 1999 concerning the implementation of regional autonomy in the context of a more efficient, effective and responsible administration of government affairs, which was revised by Law no. 32 of 2004 concerning regional government and Law no. 33 of 2004 concerning the financial balance between the central and local governments, as well as the birth of four packages of legislation, namely Law no. 17 of 2003 concerning state finances, Law no. 1 of 2001 concerning the state treasury, Law No. 15 of 2004 on auditing the management and responsibility of state finances, and Law no. 25 of 2004 concerning the national development planning system, there have 
Satia Siti Sakinah Makatita et.al. The effect of good governance and internal control systems on the performance of local governments with leadership styles as moderating variables (empirical study on SKPD South Buton Regency).

been fundamental changes in the administration of government and financial arrangements, particularly the planning and budgeting of the government and other public sector organizations (Selvi et al. 2014).

As a public sector organization, local governments are required to have performance that is oriented to the interests of the community and encourage the government to always be responsive to environmental demands, by trying to provide the best service in a transparent and quality manner as well as a good division of tasks within the government. The logical consequence of the development of community demands should be to encourage the government to be more responsible (accountable) and transparent in every policy, action, and performance produced.

Performance is a description of the achievement of the implementation of an activity or program or policy in realizing the goals, objectives, mission and vision of the organization. A list of what is to be achieved is contained in the formulation of (strategy planning an organization's). This means that to achieve good organizational performance requires high abilities and talents possessed by each individual involved in it, as well as high effort to achieve the goals that have been set (Bastian,2006).

One of the indicators to see the performance of local government is based on the value of the performance score generated on the report on the implementation of local government (LPPD). Of the 475 regencies/cities that submitted the 2019 Regional Government Implementation Report (LPPD), 93.8\% of the local governments assessed for their performance by the Ministry of Home Affairs scored above 2.00, which means high and very high. Based on these data, it can be concluded that the local government administration carried out so far has received a good category. This is different from the data in the field which shows different results about government performance. Based on the results of publications submitted by Transparency International Indonesia in 2020, it was revealed that Indonesia is still experiencing big problems in the public sector because it is included in a country with a high level of corruption (Transparency International Indonesia, 2020). The survey revealed that Indonesia's corruption perception index ranked 37 out of a total of 180 countries and territories assessed, and is perceived as one of the corrupt countries. The low corruption perception index and increasing state losses due to corruption contradict the performance scores achieved by local governments.

The factors that affect the performance of local governments according to Soeprapto (2003) in Herminingsih (2009) are (good governance) good governance and the government's internal control system as performance control. Good governance according to the World Bank (1992: 1) is defined as an implementation of solid and responsible development management, in line with the principles of democracy, efficient markets, avoidance of misallocation of investment funds, and prevention of corruption both politically and administratively, implementing budgetary discipline and creation of a legal and political framework for the growth of business activities. Implementation of the implementation of practices good governance within the government can prevent the occurrence of interest factors. The factor of interest is one of the cultures that is often found by local government officials. These interests are various, such as political interests, working outside of authority, KKN (Corruption, Collusion, and Nepotism).

In addition to good governance, another factor that affects performance is the internal control system. In accounting and organizational theory, internal control or internal control is defined as a process, which is influenced by human resources and information technology systems, which are designed to help organizations achieve a 
Satia Siti Sakinah Makatita et.al. The effect of good governance and internal control systems on the performance of local governments with leadership styles as moderating variables (empirical study on SKPD South Buton Regency).

goal or certain objective. Internal control is a way to direct, monitor, and measure the resources of an organization. It plays an important role in preventing and detecting fraud and protecting organizational resources, both tangible (such as machinery and land) and intangible (such as reputation or intellectual property rights such as trademarks). The implementation of the internal control system conceptually demands an active role and commitment from public leaders at every level of the organization. Public leadership has an influence in improving the performance of public sector organizations and in achieving organizational goals. According to Mulyadi and Rivai (2013: 42) leadership style is behavior and strategy as a result of a combination of philosophies, skills, traits, attitudes, which are often applied by a leader when trying to influence the performance of his subordinates.

South Buton Regency or abbreviated as Busel is one of the regencies in Southeast Sulawesi Province, the result of the division of Buton Regency in mid-2014 through the stipulation of Law of the Republic of Indonesia Number 16 of 2014. Towards the end of the management of the Indonesian House of Representatives for the 2009-2014 period. The problem that arises within the scope of the South Buton Regency government is the percentage of Regional Budget Realization. The achievement of the realization of the South Buton Regency State Budget in 2017 to 2018 reached the target, this means that the South Buton Regency government's performance is good. However, in the last two years, the realization of the South Buton Regency State Budget has not reached the target. In 2019 the realization of the APBN was only $76.27 \%$ where the 2019 State Revenue and Expenditure Budget transfer funds disbursed in South Buton Regency amounted to more than Rp. 550.23 billion as well as in 2020 the budget received by the region was 1 billion. realized Rp. 388 million (www.Butonselatankab.realisasianggaran.go.id)
So far, the performance of local government officials is still said to be weak. The weak performance of local government officials can be seen from the number of public complaints about local government services regarding the slow performance of the government. Service offices located in the regions tend to arrive very late, not reflecting a disciplined government, resulting in poor service performance.

The theory that is suitable to be used as a grand theory in this research is agency theory. Based on agency theory which adopts the opinion of Jensen and Meckling (1976) reveals that the agency relationship in government is between the executive and the legislature. The relationship that arises because of a contract stipulated by the legislature as a representative of the people (principal) which requires the executive or government (agent) as a service provider for the benefit of the people (Ayuwidi, 2011). Based on the background that has been put forward, the title of this research is formulated Is The Effect of Good Governance and Internal Control Systems on the Performance of Local Governments With Leadership Styles As Moderating Variables.

\section{LITERATURE REVIEW Performance}

According to Bastian (2006), performance is a description of the achievement of the implementation of an activity/program/policy in realizing the goals, objectives, mission, and vision of the organization. In general, Local Government Performance is an indicator of the level of achievement that can be achieved and reflects the success of an organization, and is the result achieved from the behavior of members of the organization.

\section{Regional government performance}

According to Law No. 12 of 2008 concerning Regional Government, what is meant by regional government is the implementation of government affairs by the Regional Government and DPRD 
Satia Siti Sakinah Makatita et.al. The effect of good governance and internal control systems on the performance of local governments with leadership styles as moderating variables (empirical study on SKPD South Buton Regency).

according to the principle of autonomy and assistance tasks with the principle of autonomy as wide as possible in the system and principles of the Unitary State of the Republic of Indonesia as referred to in the 1945 Constitution of the Republic of Indonesia.

\section{Good Governance}

The definition of good governance (good corporate governance) according to the Organizational for Economic Cooperation and Development (OECD, 1998) is a system that regulates and controls the company, whether the relationship between shareholders, management (managers) of the company, creditors, government, employees as well as other internal and external stakeholders related to their rights and obligations.

\section{Internal Control System}

The government's internal control system adopted by Indonesia is taken from the internal control system according to the GAO (Government Accounting Organization), namely the Supreme Audit Agency in the United States and according to COSO (Committee Of Sponsoring Organization of Treadway Commission), which is a commission engaged in management organization (Khasanah, 2013).

\section{Leadership Style}

The leadership style in question is the leadership theory of the leader's behavioral approach. From one point of view, this approach is still focused onleadership style. Howard $\mathrm{H}$. Hoyt (Kartini Kartono, 2009:57) states that "Leadership is the art of influencing human behavior, the ability to guide people, relationship problems and influence between leaders and those being led, emerge and develop as a result of automatic interactions between leaders and followers. led individuals".

\section{Hypothesis}

Based on the formulation of the problem and the conceptual framework that has been described, the researcher formulates the research hypothesis as follows:

1. H1: Good governance has a significant positive effect on the performance of the district government. South Buton

2. H2: Internal control has a significant positive effect on local government performance.

3. H3: Good Governance Affects Local Government Performance With Leadership Style As Moderating Variable.

4. H4: Internal Control System Positively Affects Local Government Performance With Leadership Style As Moderating Variable

\section{MATERIALS \& METHODS}

The method used in this research is descriptive research with a quantitative approach that aims to reveal something as it is. This study aims to describe and explain how the influence of good governance and internal control systems on government performance with leadership style as a moderating variable. The location of this research was carried out at the South Buton Regency SKPD office. This research was conducted for 2 months (September-October 2021). The population in this study is the Regional Work Unit (SKPD) in the South Buton Regency Government. The sampling technique used is purposive sampling. The sample criteria used in this study are employees who work in SKPD Buton Selatan who have a definite understanding and knowledge of the performance of the local government and employees who already have experience and have held positions for at least one year, because the selection of a one-year position is a relatively an organization. This research was conducted using the method survey by distributing questionnaires directly to the SKPD office of South Buton Regency, sending questionnaires, sent by the 
Satia Siti Sakinah Makatita et.al. The effect of good governance and internal control systems on the performance of local governments with leadership styles as moderating variables (empirical study on SKPD South Buton Regency).

researchers themselves directly to each office.

\section{RESULT}

The hypothesis in this study is to use multiple analysis carried out with two stages of testing. The first stage is multiple regression which is carried out without moderating variables. The second stage is a moderation regression with an absolute difference approach

The results of the analysis without moderating variables.

\begin{tabular}{|l|l|l|l|l|}
\hline \multirow{2}{*}{ Model } & \multicolumn{2}{|l|}{ Coefficients } & T & Sig. \\
\cline { 2 - 3 } & B & Std. Error & & \\
\hline (Constant) & 1,897 & 3,718 &, 510 &, 611 \\
G G &, 137 &, 068 & 2,027 & \\
\hline S P I &, 797 &, 079 & 10,090 &, 045 \\
\hline \multicolumn{5}{|l}{ Source: processed data, 2021 } \\
\hline
\end{tabular}

Based on the table above, the estimation model can be explained as follows:

$Y=1,879+0,137 X_{1}+0,797 X_{2}+e$

1) Good governance has a positive and significant effect on local government performance.

Based on the table above, it can be explained that the variable good governance has a $t$ value of 2.027 which is greater than $t$ table 1.9823, with a Beta coefficient of 0.137 and a significance level of 0.045 . Which is smaller than 0.05. Sehinggat it is concluded that good governance positive and significant effect on the performance of the local government, then $\mathrm{H}_{1}$ received.

2) The internal control system has a positive and significant effect on local government performance.

Based on the table above, it can be explained that the internal control system variable has a t count of 10.090 which is greater than $\mathrm{t}$ table 1.9823 with a Beta coefficient value of 0.797 with a significance level of 0.000 which is smaller of 0.05 . It concluded that the internal control systems and a significant positive effect on the performance of the local government, then $\mathrm{H}_{2}$ is received.
Moderation regression test results with absolute difference value approach

\begin{tabular}{|l|l|l|l|l|}
\hline \multirow{2}{*}{ Model } & \multicolumn{2}{|l|}{ Coefficients } & T & \multirow{2}{*}{ Sig. } \\
\cline { 2 - 3 } & B & Std. Error & & \\
\hline (Constant) & $52,852,704$ & $18,517,509$ & 2,854 &, 005 \\
G G & & & &, 170 \\
\hline S P I & $-1,297$ &, 485 & 1,382 &, 009 \\
\hline Leadership Sytle &,- 776 &, 426 & $-2,673$ &, 071 \\
\hline X1_M &,- 014 &, 011 & $-1,823$ &, 208 \\
\hline X2_M &, 041 &, 011 & $-1,267$ &, 000 \\
\hline \multicolumn{4}{|l|}{ Source: processed data, 2021 } \\
\hline
\end{tabular}

1) Good governance local government performance with leadership style as moderating variable

Affects From the table above it can be explained that the X1_M variable has a $\mathrm{t}$ count of -1.267 which is smaller than the $t$ table of 1.9823 , with a beta coefficient of 0.014 and a significance level of 0.208 which is greater than 0.005 . It can be concluded that leadership style is not moderating variables that strengthen the relationship between good governance of local government performance, then $\mathrm{H}_{3}$ rejected.

2) Influence of leadership style in moderating internal control system on local government performance.

Based on the table above, it can be explained that the X2_M variable has a $\mathrm{t}$ count of 3.833 which is greater than t table 1.9823 , with a beta coefficient of 0.041 with a significance level of 0.000 which is smaller than 0.05 . Thus, it can be concluded that leadership style is a moderating variable that strengthens the relationship between the internal control system and local government performance. So $\mathrm{H} 4$ is accepted.

\section{DISCUSSION}

\section{A. The Effect of Good Governance on Local Government Performance}

The results of the study indicate that good governance has a positive effect on the performance of the district government. south button. This is evidenced from the results of partial hypothesis testing (t test), the significance level of the variable is obtained, good governance namely 0.045 which is smaller than 0.05 is then seen from 
Satia Siti Sakinah Makatita et.al. The effect of good governance and internal control systems on the performance of local governments with leadership styles as moderating variables (empirical study on SKPD South Buton Regency).

the multiple regression coefficient of the variable good governance of 2.027. The results of respondents' responses to good governance with an average value of 4.26 which are at the level of strongly agree, The highest respondent's answer is in the sixth statement, namely the local government develops programs that are oriented towards improving the welfare of the community with a score of 4,486 .

\section{B. The Influence of the Internal Control System on the Performance of the Regional Government of Kab. South Buton}

The results showed that the internal control system had a positive effect on the performance of the district government. south button. This is evidenced by the results of the partial hypothesis test ( $t$ test), the significance level of the internal control system variable is obtained that is 0.000 Which is smaller than 0.05 then seen from the multiple regression coefficient of the internal control system variable of 10,090. The results of respondents' responses to the internal control system with an average value of 4.07 which is at the level of agree, The highest respondent's answer is in the eleventh statement, namely the SKPD always follows up on any findings/reviews and suggestions given by the BPK/inspectorate with a score of 4.549 .

\section{The Effect of Good Governance on} Local Government Performance With Leadership Style As Moderating Variable

The results showed that leadership style could not moderate the effect of good governance on local government performance. This is evidenced by the results of the moderated partial $\mathrm{T}$ test, which obtained a significance level of 0.208 which is smaller than 0.005. Furthermore, it can be seen from the $\mathrm{t}$-count value of -1.267 . This shows that leadership style does not moderate the relationship between the influence of good governance and local government performance. This could be due to the fact that the previous regent's short leadership period had not been able to prove the impact of his leadership style on the resulting performance.

\section{The Effect of Internal Control System on Local Government Performance With Leadership Style As Moderating Variable}

The results show that leadership style can moderate the relationship between the internal control system on local government performance. This is evidenced by the results of the moderated partial $\mathrm{T}$ test, which obtained a significance level of 0.000 which is smaller than 0.005 . Furthermore, it is seen from the t-count value of 3.833 . This shows that the leadership style moderates the influence of the internal control system on local government performance.

\section{CONCLUSION}

A. There is an influence of good governance on the performance of local government in the district. South Buton. This is supported by the highest respondent's answer being in the sixth statement, the average respondent answered strongly agree. This means that the performance of local governments is influenced by the implementation of good governance. Transparency is an important indicator in the implementation of good governance in government, with good transparency it can provide security, openness and order in the preparation of the KPD budget so as to prevent information asymmetry among users of financial statements.

B. There is the influence of the internal control system on the performance of local government in the district. South Buton. This is supported by the highest respondents' answers are in the eleventh statement with the average respondent answering agree. This means that a high internal control system can improve the performance of local governments. This is in line with the monitoring indicators in internal control. Where the results of 
Satia Siti Sakinah Makatita et.al. The effect of good governance and internal control systems on the performance of local governments with leadership styles as moderating variables (empirical study on SKPD South Buton Regency).

the KPD's performance are always reviewed and given advice by the BPK. This can help improve performance and control budget flows so that irregularities do not occur.

C. The leadership style cannot moderate the influence of good governance on the performance of the district government. South Buton. This can be proven by the results of the partial T-test of moderation which obtained a significance value smaller than the value of 0.005 . This could be due to the fact that the previous regent's short leadership period had not been able to prove the impact of his leadership style on the resulting performance. This can be clarified by the results of respondents' responses on the indicators of supportive leadership with an average respondent of 3,540 which means it is lower than other indicators. Where supportive leadership involves the leader in formulating and making decisions.

D. Leadership style can moderate the influence of the internal control system on the performance of the district government. South Buton. This can be proven by the results of the partial T-test of moderation which obtained a significance value greater than the value of 0.005 . This can mean that the leader has implemented good governance internal control, as well as performance control to control the risk of accounting system violations in accordance with the control environment indicators, this indirectly increases performance retention.

\section{Acknowledgement: None \\ Conflict of Interest: None \\ Source of Funding: None}

\section{REFERENCES}

1. Abdulla, Syukury. 2006. Hubungan dan Masalah Keagenan di Pemerintahan Dearah: Sebuah Peluang Penelitian Anggaran dan Akuntansi. Jurnal Akuntansi Pemerintahan. Vol. 2(1).
2. Afrina, Dina. 2015. Pengaruh Penerapan Sistem Akuntansi Pemerintah Daerah, Pengendalian Intern Dan Sistem Pelaporan Terhadap Akuntabilitas Kinerja Instansi Pemerintah (Studi Persepsian Pada Satuan Kerja Perangkat Daerah Kota Pekanbaru). Jom FEKON Vol. 2 No. 2.

3. Bastian, indra. 2006. Akuntansi Sektor Publik: Suatu Pengantar, Jakarta:Erlangga.

4. Herminingsih. 2009. Pengaruh partisipasi dalam penganggaran dan peran manajerial pengelola keuangan daerah terhadap kinerja pemerintah daerah (studi empiris pada pemerintah kabupaten demak. Tesis. Semarang: Program Pascasarjana Akuntansi Universitas Diponegoro

5. Kharisma, Bayu. 2014. Good Governance Sebagai Suatu Konsep Dan Mengapa Penting Dalam Sektor Publik Dan Swasta (Suatu Pendekatan Ekonomi Kelembagaan). Jurnal Buletin Studi Ekonomi, Vol. 19, No. 1

6. Nurbaeti, Darya Setia. 2020. Pengaruh Good Governance Dan Sistem Pengendalian Intern Pemerintah Terhadap Kinerja Aparatur Pemerintah Daerah Dan Implikasinya Pada Pelayanan Publik (Studi Kasus Di Pemerintah Kabupaten Garut). Prosiding Industrial Research Workshop And National Seminar (POLBAN), (Online). Vol. 10, No. (https://doi.org/10.35313/irwns.v10i1.1430, diakses 2 april 2021)

7. Pratiwi, Bondan Wahyusari. 2020. Peran Aparat Pengawasan Intern Pemerintah Dalam Pencepatan Penanganan Darurat Covid-19 Di Lingkungan Pemerintah Daerah. Jurnal Pengawasan. Vol. 2, No, 2. ISSN 2868-2840.

8. Rahman, Sitti Hartini. 2021. Pengaruh Penerapan Good Governance danPengendalian Internal terhadap Kinerja PengelolaanKeuangan Pemerintah Daerah di Kota Makassar (Online). (http://journal.1ldikti9.id/Equilibrum, di akses 2 april 2021). Vol 2(1) ISSN: 26854651

9. Republik Indonesia, Peraturan Pemerintah Nomor 8 Tahun 2008 tentang Pelaporan Keuangan dan Kinerja Pemerintah Daera. Jakarta: Departemen Keuangan Republik Indonesia

10. Republik Indonesia, Undang-Undang Nomor 23 Tahun 2014 tentang Pemerintah 
Satia Siti Sakinah Makatita et.al. The effect of good governance and internal control systems on the performance of local governments with leadership styles as moderating variables (empirical study on SKPD South Buton Regency).

Daerah. Jakarta: Kementrian Hukum dan Hak Asasi Manusia.

11. Sardjito, Bambang Dan Osmad Muthaher. 2007. Pengaruh Partisipasi Penyusunan Anggaran Terhadap Kinerja Aparat Pemerintah Daerah: Budaya Organisasi Dan Komitmen Organisasi Sebagai Variabel Moderating

12. Sekaran, Umar. 2006. Metodologi Penelitian Untuk Bisnis, Edisi 4, Buku 1. Jakarta: Salemba Empat

Sugiyono. 2012. Metode Penelitian Bisnis (Pendekatan Kuantitatif, Kualititatif dan $R \& D)$. Bandung: Alfa Beta

13. Suryani, \& Hendryadi. (2015). Metode riset kuantitatif teori dan aplikasi pada penelitian bidang Manajemen dan Ekonomi Islam. Jakarta: Kencana Prenadamedia Group.

14. Undang-Undang Republik Indonesia Nomor 1 tahun 2001 Tentang Bendahara Negara, 2001. Jakarta: kementrian keuangan Republik Indonesia.

15. Undang-Undang Republik Indonesia Nomor 17 tahun 2003 Tentang Keuangan Negara, 2003. Jakarta: kementrian keuangan Republik Indonesia.
16. Undang-Undang Republik Indonesia Nomor 33 tahun 2004 Tentang Perimbunan Keuangan, 2004. Jakarta: kementrian keuangan Republik Indonesia.

17. Wati, L. N., Rachmat Sudarsono, S. E., Si, M., \& Erie Febrian, S. E. 2016. Corporate Governance On Conglomerates Pollitically Connected. International Journal of Business, Economics and Law, 10(1), 23-31.

18. Yuni Lestari (2016). Pengaruh Good Governance Gaya Kepemimpinan Komitmen Organisasi dan Pengendalian Intern Terhadap Kinerja Instansi Pemerintah. JOM Fikom. Vol.3(1).

How to cite this article: Satia Siti Sakinah Makatita, Kartini, Sri Sundari. The effect of good governance and internal control systems on the performance of local governments with leadership styles as moderating variables (empirical study on SKPD South Buton Regency). International Journal of Research and Review. 2022; 9(1): 553-560. DOI: https://doi.org/10.52403/ijrr.20220164 